\title{
Computational fluid dynamics analysis of cylindrical floating breakwater towards reduction of sediment transport
}

\author{
A. Fitriadhy*, M.A. Faiz and S.F. Abdullah \\ Program of Maritime Technology, School of Ocean Engineering, \\ Universiti Malaysia Terengganu, Malaysia. \\ *Email: naoe.afit@ gmail.com \\ Phone:+6096683856; Fax: +6096683193
}

\begin{abstract}
Floating breakwater becomes an alternative and reliable coastal area protection as it is cheaper in production cost as compared to conventional bottom-fixed breakwater. Floating breakwater system would be the best decision in order to control sedimentation that threatens the shore due to erosion. This study proposes to analyse Cylindrical Floating Breakwater (CFB) aimed at gaining a sufficient reduction in the sediment transport rate along the shore (case study at Tok Jembal Beach in Kuala Terengganu) by using CFD approach. Several parameters for the effects of wavelengths and vertical clearance between the CFB and seabed on the gradient of suspended and packed sediment were simulated by using Flow3D. A wave boundary was assigned to give an insight on regular waves effects to the parameters used in the simulation. The results showed that the presence of CFB markedly reduced the concentration and mass of suspended sand, gravel and coarse gravel for the whole range of wavelengths considered. Besides, it was found that varying the relative clearance of the floating breakwater and seabed was particularly sensitive to the concentration and mass of suspended sediment. Meanwhile, the bulk of sediment mass and concentration remain insignificant for the investigated wavelength and vertical clearance. From this standpoint, the cylindrical floating breakwater (CFB) could significantly minimise the gradient of sediment transport along the breakwater-beach distance while its installation depth may be optimised for circumstances to save cost, avoid breaking waves and morphological changes, ship traffic routes and etc.
\end{abstract}

Keywords: Coastal protection; cylindrical floating breakwater; sediment transport; computational fluid dynamics.

\section{INTRODUCTION}

Floating breakwaters seem to be a smart solution for shoreline protection alternative againsthard approaches such as armoring and traditional breakwaters. In recent years, many available CFB types, such like simple structures like pontoon or cylindrical floating breakwater (CFB), have gained many interests. Among the advantages of using these inflatable breakwaters include their flexibility for either temporary or permanent use, transportability, cost effectiveness and ease of construction and installation $[1,2]$. Meanwhile, the versatility of these structures is increasingly recognised, especially for marine culture which renders it as favourable and economical [3]. Some specific research in this type of breakwater involve several parametric studies that is devoted to the stability and performance of structures under various loading conditions [4-6]. Several researchers had conducted numerous approaches in order to analyse the hydrodynamic performance 
of floating breakwater of moored pontoon type breakwater [7-9], inclined moored submerged floating breakwater [10] and porous floating breakwater [11]. Despite numerous research and promising results by many authors, unsatisfactory wave attenuating effect of floating breakwater in long waves has remain a topic of studies by many researchers [12-15]. In this regard, many cost effective floating breakwaters were introduced by manipulating its relative width and draft, specifically to attenuate up and down waves. Overall, many improvements and positive results were obtained by researchers in the field of floating breakwaters. However, research development is still scarce. Little knowledge is known about the interaction between floating breakwater and sediment transport [16]. It is favourable for sites with a large variation in tide and wave directions. Furthermore, it is not to intercept or reflect all incoming waves and totally alter sediment transport. However, it should potentially manage the littoral transport in a smoother manner, if an effective design could be linked. There is a clear and large gap between the current technology and demand in hydrodynamics and sediment transport knowledge relating to floating breakwaters.

To achieve the objective, a reliable approach to adequately capture the complex dynamic phenomena is obviously needed. This is important so that the complicated flow and turbulence patterns as well as the force fields induced by different wave attacks can be accurately predicted while not ignoring large motions of the breakwater. This paper presents a prediction on hydrodynamic performance of cylindrical floating breakwater (CFB) towards the reduction of sediment erosions under regular waves by using the Computational Fluid Dynamics (CFD) approach. The numerical study focused on the concentration of suspended and packed sediment, with and without CFB, as well as the mooring CFB tension and motion response of the breakwater. Meanwhile, in the present study, several parameters of various wavelengths from $2 \mathrm{~m}$ to $8 \mathrm{~m}$ and clearance between CFB and seabed within the range of $2 \mathrm{~m}$ to $8 \mathrm{~m}$ are deliberately investigated.

\section{METHODS AND MATERIALS}

\section{Governing Equation}

The CFD flow solver on Flow3D version 10.1 is based on the incompressible unsteady RANS equations in which the solver applies Volume of Fluid (VOF) to track the free surface elevation. The interface between fluid and solid boundaries is simulated with the fractional area volume obstacle representation favour method [10]. This method computes open area and volume in each cell to define the area that is occupied by obstacles [17]. Flow3D employs the meshing method FAVOR ${ }^{\mathrm{TM}}$ that dramatically improves problem setup by embedding the geometry directly into the mesh, and allowing for rapid parametric adjustments without the labour-intensive remeshing required by other CFD software.

\section{Continuity and momentum equation}

The continuity and momentum equations for a moving object and the relative transport equation for VOF function are:

$$
\begin{aligned}
& \frac{V_{f}}{\rho} \frac{\partial \rho}{\partial t}+\frac{1}{\rho} \nabla \cdot\left(\rho \vec{u} A_{f}\right)=-\frac{\partial V_{f}}{\partial t} \\
& \frac{\partial \vec{u}}{\partial t}+\frac{1}{V_{f}}\left(\vec{u} A_{f} \cdot \nabla \vec{u}\right)=-\frac{1}{\rho}\left[\nabla_{\rho}+\nabla \cdot\left(\tau A_{f}\right)\right]+\vec{G} \\
& \frac{\partial F}{\partial t}+\frac{1}{V_{f}} \nabla \cdot\left(F \vec{u} A_{f}\right)=-\frac{F}{V_{f}} \frac{\partial V_{f}}{\partial t}
\end{aligned}
$$


where $\rho$ is the density of fluid, $\vec{u}$ is the fluid velocity, $V_{f}$ is the volume fraction, $A_{f}$ is the area fraction, $p$ is the pressure, $\tau$ is the viscous stress tensor, $G$ denotes gravity and $F$ is the fluid fraction.

In the case of coupled GMO's motion, Equation (1) and Equation (2) are solved at each time step and the location of all moving objects is recorded and the area and volume fractions was updated by using the FAVOR technique. Equation (3) is solved with the source term $\left(-\frac{\partial V_{f}}{\partial t}\right)$ on the right-hand side which is computed as:

$-\frac{\partial V_{f}}{\partial t}=\vec{U}_{o b j} \cdot \vec{n} S_{o b j} / V_{c e l l}$

where $S_{o b j}$ is the surface area, $\vec{n}$ surface normal vector, $\vec{U}_{o b j}$ is the velocity of the moving object at a mesh cell and $V_{\text {cell }}$ is the total volume of the cell [17].

\section{Turbulence model}

The RNG turbulence model was used for the simulation of exchange flow between open water and floating object, since it accounted for low Reynolds number effects [18-20]. Applying the double averaging strategy to the transport equations for TKE and its dissipation rate produced the turbulence model for flow. The resulting equations were:

$$
\begin{aligned}
& \frac{\delta \mathrm{k}}{\delta \mathrm{t}}+\mathrm{U}_{\mathrm{j}} \frac{\delta \mathrm{k}}{\delta \mathrm{x}_{\mathrm{j}}}=\frac{\delta}{\delta \mathrm{x}_{\mathrm{j}}}\left[\left(\mathrm{v}+\frac{\mathrm{v}_{\mathrm{t}}}{\sigma_{\mathrm{k}}}\right) \frac{\delta \mathrm{k}}{\delta \mathrm{x}_{\mathrm{j}}}\right]+\mathrm{P}_{\mathrm{k}}+\mathrm{B}_{\mathrm{k}}+\mathrm{W}_{\mathrm{k}}-\varepsilon \\
& \frac{\delta \varepsilon}{\delta \mathrm{t}}+\mathrm{U}_{\mathrm{j}} \frac{\delta \varepsilon}{\delta \mathrm{x}_{\mathrm{j}}}=\frac{\delta}{\delta \mathrm{x}_{\mathrm{j}}}\left[\left(\mathrm{v}+\frac{\mathrm{v}_{\mathrm{t}}}{\sigma_{\varepsilon}}\right) \frac{\delta \varepsilon}{\delta \mathrm{x}_{\mathrm{j}}}\right]+\mathrm{C}_{1 \varepsilon} \frac{\varepsilon}{\mathrm{k}}\left(\mathrm{P}_{\mathrm{k}}+\mathrm{B}_{\mathrm{k}}\right)\left(1+\mathrm{C}_{3 \varepsilon} \mathrm{R}_{\mathrm{f}}\right)+\mathrm{W}_{\varepsilon}-\mathrm{C}_{2 \varepsilon}^{*} \frac{\varepsilon^{2}}{\mathrm{k}} \\
& \mathrm{P}_{\mathrm{k}}=\mathrm{v}_{\mathrm{t}} \mathrm{S}^{2}=\mathrm{v}_{\mathrm{t}}\left(\frac{\delta \mathrm{U}_{\mathrm{i}}}{\delta \mathrm{x}_{\mathrm{j}}}+\frac{\delta \mathrm{U}_{\mathrm{j}}}{\delta \mathrm{x}_{\mathrm{i}}}\right) \frac{\delta \mathrm{U}_{\mathrm{i}}}{\delta \mathrm{x}_{\mathrm{j}}} \\
& \mathrm{B}_{\mathrm{k}}=\beta \mathrm{g}_{\mathrm{i}} \frac{\mathrm{v}_{\mathrm{t}}}{\sigma_{\mathrm{s}}} \frac{\delta \mathrm{s}}{\delta \mathrm{x}_{\mathrm{i}}}
\end{aligned}
$$

where $\mathrm{P}_{\mathrm{k}}$ is the shear production term of TKE, $S=\sqrt{2 S_{i j} S_{j i}}$ is the modulus of the mean rate of strain tensor and $S_{i j}=\frac{1}{2}\left(\frac{\delta U_{i}}{\delta x_{j}}+\frac{\delta U_{j}}{\delta x_{i}}\right), B_{k}$ is the buoyant production term of TKE, $W_{k}$ is the wake production tern of TKE, $W_{\varepsilon}$ is the wake production term in $\varepsilon, \sigma_{k}$ and $\sigma_{\varepsilon}$ are the turbulent Prandtl numbers for $k$ and $\varepsilon$, and $C_{i \varepsilon}, C_{3 \varepsilon}$ and $C_{2 \varepsilon}^{*}$ are the model coefficients.

\section{Regular Wave Theory}

Based on the Airy's linear wave theory and assumptions, the regular wave equation for the free surface elevation $\eta(x, t)$, the velocity potential $\varphi(x, z, t)$, and velocity components in $x$ and $z$ directions $u(x, z, t)$ and $\mathfrak{w}(x, z, t)$ are rewritten as [17]:

$$
\begin{aligned}
& \eta=A \cos (k x-\omega t+\phi) \\
& \varphi(x, z, t)=x U+\frac{A \omega \cosh [k(z+h)] \sin (k x-\omega t+\phi)}{k \sinh k h} \\
& u(x, z, t)=U+\frac{A \omega \cosh [k(z+h)] \cos (k x-\omega t+\phi)}{\sinh k h} \\
& \mathfrak{w}(x, z, t)=\frac{A \omega \sinh [k(z+h)] \sin (k x-\omega t+\phi)}{\sinh k h}
\end{aligned}
$$

where $\omega$ is the angular frequency, $k$ is the wave number and $\phi$ is the phase shift angle. The dispersion equation in terms of wave speed $c=\omega / k$ is given by: 
$(c-U)^{2}=\frac{g}{k} \tanh k h$

\section{Bedload Transport}

The dimensionless form of the bedload transport rate for species $\mathrm{n}$ is redefined in Equation (14) as [21]:

$$
\emptyset_{n}=\frac{q_{b, n}}{\left[g\left(s_{n}-1\right) d_{n}{ }^{3}\right]^{\frac{1}{2}}}
$$

where $q_{b . n}$ is the volumetric bedload transport rate per unit bed width (in units of volume per width per time). $\emptyset_{n}$ is calculated by using the Meyer-Peter and Muller equation [21]:

$\emptyset_{n}=B_{n}\left(\theta_{n}-\theta_{c r, n}\right)^{1.5} c b, n$

where $B_{n}$ is the bedload coefficient. It is generally 5.0 to 5.7 for low transport, around 8.0 for intermediate transport, and up to 13.0 for very high transport (for example, sand in sheet flow under waves and currents). The default value used in FLOW3D is 8.0, which is the most commonly used value in literature [17]. $c_{b, n}$ is the volume fraction of species $n$ in the bed material:

$c_{b, n}=\frac{\text { net volume of species, } n}{(\text { net volume of } n \text { net volumeof all species) }}$

and satisfies

$\sum_{n=1}^{N} c_{b, n}=1.0$

where $\mathrm{N}$ is the total number of species. Note that $c_{b, n}$ does not exist in the original MeyerPeter and Muller's equation. It is added in Equation (10) to account for the effect of multiple species.

The relationship in [22] is used to estimate the bedload layer thickness $h_{n}$ :

$h_{n}=0.3 d_{n} d_{s, n}^{0.7}\left(\frac{\theta_{n}}{\theta_{c r, n}}-1\right)^{0.5}$

The bedload velocity, $u_{b, n}$ is determined by:

$u_{b, n}=\frac{q_{b, n}}{h_{n} c_{b, n} f_{b}}$

where $f_{b}$ is the total packing fraction of sediments. Both $u_{b, n}$ and $q_{b, n}$ are in the fluid flow direction adjacent to the bed interface.

\section{Suspended Load Transport}

For each species, the suspended sediment concentration is solved by by using transport equation [23]:

$\frac{\partial C_{s, n}}{\partial t}+\nabla \cdot\left(C_{s, n} u_{s, n}\right)=\nabla \cdot \nabla\left(D C_{s, n}\right)$ 
Here, $C_{s, n}$ is the suspended sediment mass concentration, which is defined as the sediment mass per volume of fluid-sediment mixture, $D$ is the diffusivity and $u_{s, n}$ is the sediment velocity of species $n$. It is noted that each sediment species in suspension moves at its own velocity that is different from those of fluid and other species. This is because grains with different mass densities and sizes have different inertia and receive different drag force.

Correspondingly, the suspended sediment volume concentration $c_{s, n}$ is defined as the suspended sediment species $n$ volume per volume of fluid-sediment mixture. It is related to $C_{s, n}$ by:

$c_{s, n}=\frac{c_{s, n}}{\rho_{n}}$

The mass density of the fluid-sediment mixture is calculated using [24]:

$\bar{\rho}=\sum_{m=1}^{N} c_{s, m} \rho_{s, m}+\left(1-c_{s, t o t}\right) \rho_{f}$

where $c_{s, t o t}$ is the total suspended sediment volume concentration,

$c_{s, t o t}=\sum_{m=1}^{N} c_{s, m}$

To solve Equation(16) for $C_{s, n}, u_{s, n}$ must be calculated first. It is assumed that the grains in suspension do not have strong interactions with each other, the velocity difference between the suspended sediments and the fluid-sediment mixture is mainly the settling velocity of grains, $u_{\text {settle } n}$ that is defined in Equation Eq.(19). Thus, $u_{s, n}$ is evaluated by using:

$u_{s, n}=\bar{u}+u_{s e t t l e, n} c_{s, n}$

where $\bar{u}$ is the bulk velocity of the fluid-sediment mixture,

$\bar{u}=\sum_{m=1}^{N} c_{s, n} u_{s, m}+\left(1-c_{s, t o t}\right) u_{f}$

In Flow3D, $\bar{u}$ is obtained by solving the continuity and Navier-Stokes equations with a turbulence closure model.

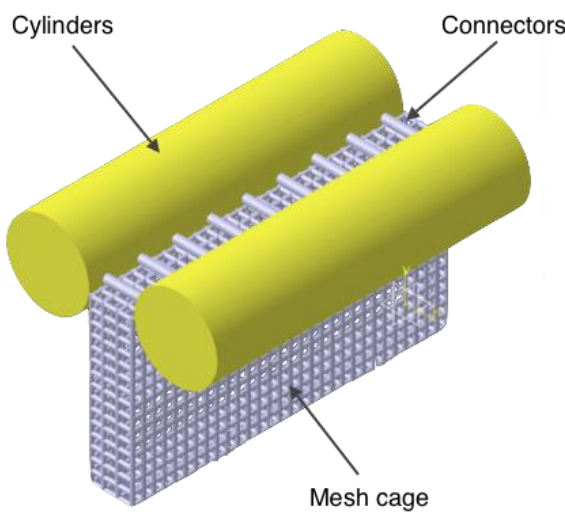

Figure 1. Geometry of cylindrical floating breakwater (CFB) 


\section{Simulation Condition \\ CFB Model}

The geometry and configuration of the cylindrical floating breakwater was shown in Figure 1 . The CFB is made out of two $4 \mathrm{~m}$ (diameter) $\mathrm{x} 15.2 \mathrm{~m}$ (length) cylinders and nine $0.4 \mathrm{~m}$ (diameter) $\mathrm{x} 2 \mathrm{~m}$ (length) cylinders and the $15.2 \mathrm{~m}$ long (

Figure 1), $2 \mathrm{~m}$ wide and $8 \mathrm{~m}$ high mesh cage also be hung below the main structure with no mesh balls [14].

\section{Parametric studies}

For this particular study, several parametric studies, such as the effects of the wavelengths and vertical clearance between floating breakwater and seabed on the sediment transport with and without the presence of floating breakwater, are employed. Here, the various wavelengths and vertical clearances were in the range of $1.56 \mathrm{~m}$ to $24.94 \mathrm{~m}$ and $2.0 \mathrm{~m}$ to $8.0 \mathrm{~m}$, respectively, and are represented in Table 1 and Table 2.

Table 1. Effect of various wavelengths.

\begin{tabular}{lcc}
\hline $\begin{array}{l}\text { Wavelength, L } \\
(\mathrm{m})\end{array}$ & $\begin{array}{l}\text { Packed sediment concentration (PSC), Suspended sediment concentration } \\
\text { (SSC), Packed sediment mass (PSM), and Suspended sediment mass (SSM) }\end{array}$ \\
\cline { 2 - 3 } & \multicolumn{3}{c}{ Without CFB } \\
\hline 1.560 & \multicolumn{3}{c}{ Coarse sand } \\
6.239 & Gravel \\
14.037 & & Coarse gravel \\
24.940 & & \\
\hline
\end{tabular}

Table 2. Effect of various vertical clearances.

\begin{tabular}{lcc}
\hline $\begin{array}{l}\text { Vertical } \\
(\mathrm{m})\end{array}$ & clearances & $\begin{array}{l}\text { Total packed sediment mass (TPM), Total suspended sediment mass } \\
(\mathrm{TSM}) \text { and Suspended sediment concentration (SSC) }\end{array}$ \\
\hline 2.0 & Coarse sand \\
4.0 & Gravel \\
6.0 & Coarse gravel \\
8.0 & \\
\hline
\end{tabular}

\section{Computational Domain and Meshing Generation}

Computational domain of the CFB model associated with rectangular grids is shown in Figure 2. An extra refinement of the mesh, so-called the nested-block, is added to locally increase the meshing resolution $[25,26]$. Apart from that, three types of sediment species were used in the model; coarse sand, gravel and coarse gravel with diameters of $0.005 \mathrm{~m}$, $0.0138 \mathrm{~m}$ and $0.021 \mathrm{~m}$, respectively. The density for coarse sand was set at $1560 \mathrm{~kg} / \mathrm{M}^{3}$ while gravel was set at $1760 \mathrm{~kg} / \mathrm{M}^{3}$ and coarse gravel was set at $2000 \mathrm{~kg} / \mathrm{M}^{3}$ [24]. The turbulence model for this scour-type simulations, which is based on the Renormalised Group (RNG), is selected because the dynamically computed maximum turbulent mixing length relies on an algorithm developed for single-phase flow. Furthermore, the method was the most accurate and robust model available in the software that could simulate best as the real-world problems. Besides, the boundary conditions were set as in Table 3. In the study, this CFB was restrained by four mooring lines (see Figure 2). The type of mooring line used was Dyneema ${ }^{\circledR}$ D-ROPE SK 62 with 12 strands plaited. After all appropriate settings were done; the simulations were run for aforementioned study 
parameters to predict the sloping bed sediment erosion in the absence and presence of CFB. Here, CFD software so-called Flow-3D was used to visualise the scour characteristics of the above cases as displayed in Figure 3. Finally, the results of sediment concentration and mass were gathered and properly managed.

Table 3. Boundary conditions for each face

\begin{tabular}{cc}
\hline Boundary Location & Type \\
\hline X-min (Back) & Outflow \\
X-max (Front) & Wave \\
Y-min (Side) & Symmetry \\
Y-min (side) & Symmetry \\
Z-min (side) & Wall \\
Z-max (side) & Symmetry \\
\hline
\end{tabular}

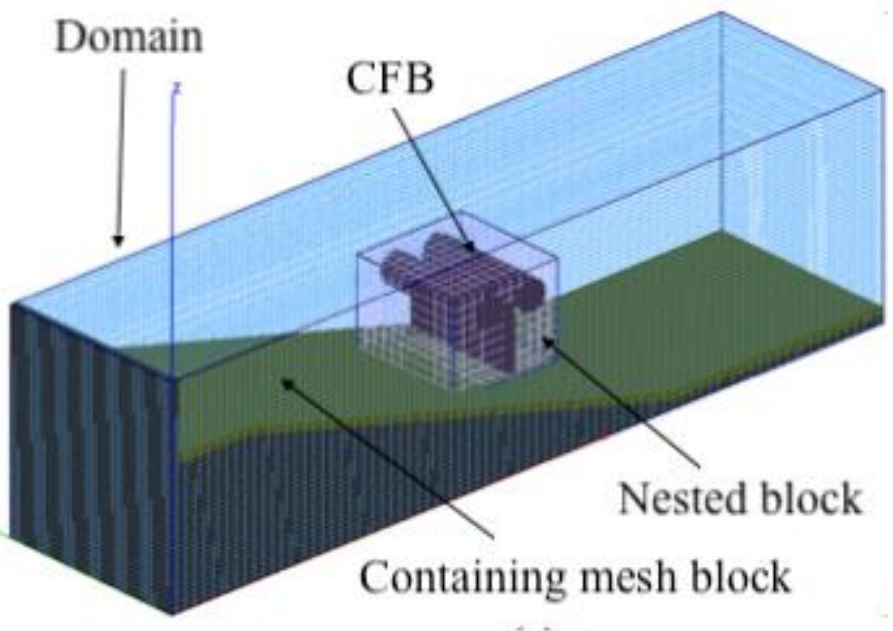

(a)

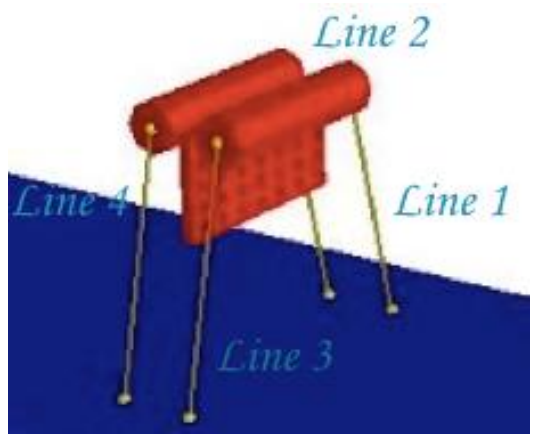

(b)

Figure 2. (a) Multi-block mesh in the computational domain, (b)mooring line configuration.

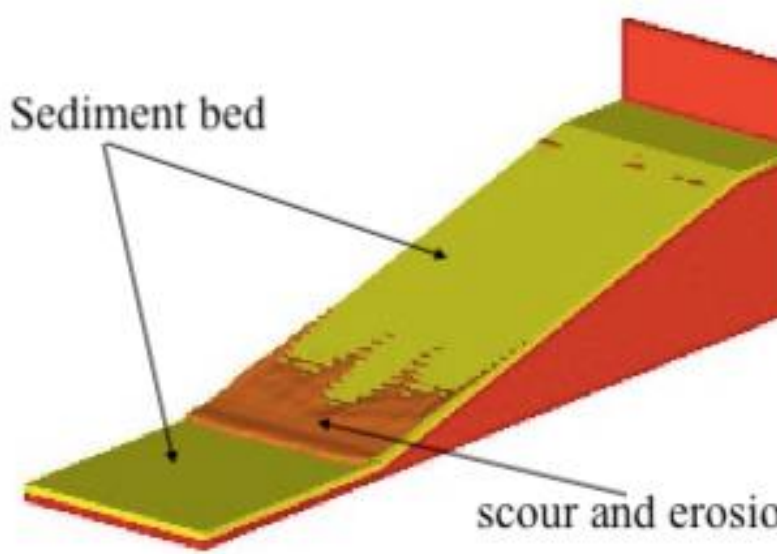

(a)

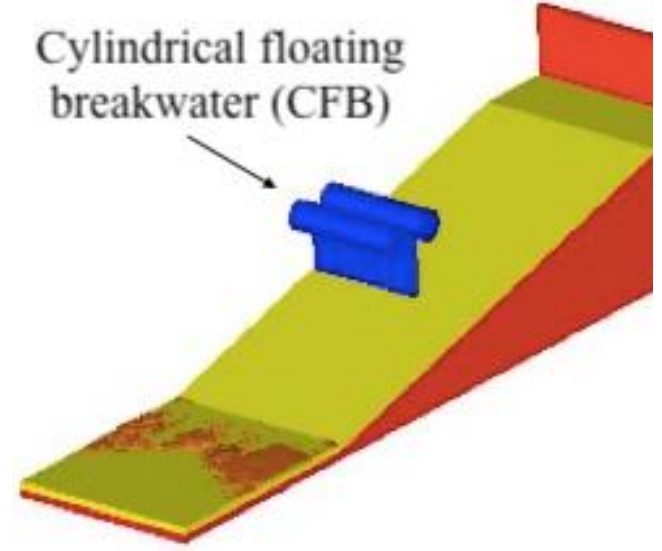

(b) 
Figure 3. Pattern of sediment scour (a) without CFB, (b) with CFB.

\section{Mesh independent study}

Mesh independent study is necessary for examining the adequate number of mesh in order to ensure the computation results accuracy. Table 4 shows the result of the mesh independent study. The total number of cells, about 3,765,500 in the case of C, was then selected from all the cases with reasonable accuracy of CFD solution associated with less computational time. Table 4 shows the mesh independent study of the system in case of wavelength, $\mathrm{L}=24.94 \mathrm{~m}$ for average packed sediment concentration (PSC); gravel with cylinder floating breakwater (CFB).

Table 4. Mesh independent study.

\begin{tabular}{ccc}
\hline Case & Total number of real cell & PSC with CFB $(\mathrm{mg} / \mathrm{l})$ \\
\hline A & $1,495,714$ & 210.0313 \\
B & $2,503,732$ & 210.0221 \\
C & $3,765,500$ & 209.0144 \\
D & $5,084,064$ & 209.0152 \\
\hline
\end{tabular}

\section{RESULTS AND DISCUSSION}

\section{Effect of Wavelengths}

The floating breakwater was run with four different wavelengths (L) in regular wave condition. The simulation was run to analyse the concentration of suspended and packed sedimentation, total mass of suspended, packed sediment for each species and fluid elevation under different wavelengths, in comparison with and without the presence of the floating breakwater.

Table 5. Average packed sediment concentration (PSC).

\begin{tabular}{ccccccc}
\hline $\begin{array}{c}\text { Wavelength, } \\
\text { L }(\mathrm{m})\end{array}$ & \multicolumn{3}{c}{ PSC without FB $(\mathrm{mg} / \mathrm{l})$} & \multicolumn{3}{c}{ PSC with CFB $(\mathrm{mg} / \mathrm{l})$} \\
\cline { 2 - 7 } & $\begin{array}{c}\text { Coarse } \\
\text { sand }\end{array}$ & Gravel & $\begin{array}{c}\text { Coarse } \\
\text { gravel }\end{array}$ & $\begin{array}{c}\text { Coarse } \\
\text { sand }\end{array}$ & Gravel & $\begin{array}{c}\text { Coarse } \\
\text { gravel }\end{array}$ \\
\hline 1.5600 & 137.3759 & 158.1401 & 183.9676 & 161.2306 & 209.0829 & 234.9920 \\
6.2390 & 188.7687 & 210.4113 & 238.0960 & 185.2898 & 209.0189 & 237.5155 \\
14.0370 & 185.3028 & 209.0231 & 237.5179 & 185.2939 & 209.0190 & 237.5156 \\
24.9400 & 185.2808 & 209.0148 & 237.5145 & 185.2804 & 209.0144 & 237.5140 \\
\hline
\end{tabular}

Table 6. Average suspended sediment concentration (SSC).

\begin{tabular}{ccccccc}
\hline $\begin{array}{c}\text { Wavelength, } \\
\text { L }(\mathrm{m})\end{array}$ & \multicolumn{3}{c}{ SSC without FB $(\mathrm{mg} / \mathrm{l})$} & \multicolumn{3}{c}{ SSC with CFB $(\mathrm{mg} / \mathrm{l})$} \\
\cline { 2 - 7 } & $\begin{array}{c}\text { Coarse } \\
\text { sand }\end{array}$ & Gravel & $\begin{array}{c}\text { Coarse } \\
\text { gravel }\end{array}$ & $\begin{array}{c}\text { Coarse } \\
\text { sand }\end{array}$ & Gravel & $\begin{array}{c}\text { Coarse } \\
\text { gravel }\end{array}$ \\
\hline 1.5600 & 68.3096 & 75.0118 & 73.7523 & 68.0285 & 13.3967 & 4.3151 \\
6.2390 & 8.31772 & 03.0635 & 1.1024 & 0.2204 & 0.0194 & 0.0105 \\
14.0370 & 0.2344 & 0.0217 & 0.0128 & 0.0433 & 0.0200 & 0.0132 \\
24.9400 & 0.0202 & 0.0112 & 0.0081 & 0.0276 & 0.0140 & 0.0096 \\
\hline
\end{tabular}


Referring to Table 5, the average packed sediment concentration at the floor of the seabed, $\frac{m g}{L}$ for all species decrease in the cylindrical floating breakwater (CFB). However, at $\mathrm{L}=1.56 \mathrm{~m}$ with the presence of $\mathrm{CFB}$ as compared to without $\mathrm{CFB}$, coarse sand, gravel and course gravel had showed increment in the average packed sediment concentration by $14.8 \%, 24.36 \%$ and $21.71 \%$, respectively. As the wavelength increases, coarse sand and coarse gravel show increment in average concentration by $12.98 \%$ and $1.06 \%$, respectively, while gravel shows decrement of concentration in the presence of CFB. In Figure 4(a), it is shown that the gravel species were almost the same packed sediment concentration, $\frac{m g}{L}$ for the whole wavelengths considered in the study. The detailed results are summarised in Table 5. Meanwhile, the average packed sediment concentration without breakwater is lower than the one with floating breakwater at $\mathrm{L}=$ 1.56 for coarse sand and gravel species. For higher wavelengths, however, the packed sediment concentration with floating breakwater is slightly lower as compared to without floating breakwater for both species. Again, at maximum L, the packed sediment concentration is almost the same for all the species with and without floating breakwater. Sediment transport in the nearshore depends primarily on the strength of currents and the oscillatory velocities at the seabed produced by waves [27], thus, as cylindrical floating breakwater is moored through the seabed, the current strength is uneven and led to a different average concentration for all species. The results on average suspended sediment concentration are represented in Table 6 . As the wavelength increases, the concentration of all species reduces in the presence of CFB. However, at $\mathrm{L}=24.94 \mathrm{~m}$, for all species, the concentration grows by $26.81 \%, 20 \%$ and $15.63 \%$, respectively, in the presence of CFB as compared to in the absence of CFB.

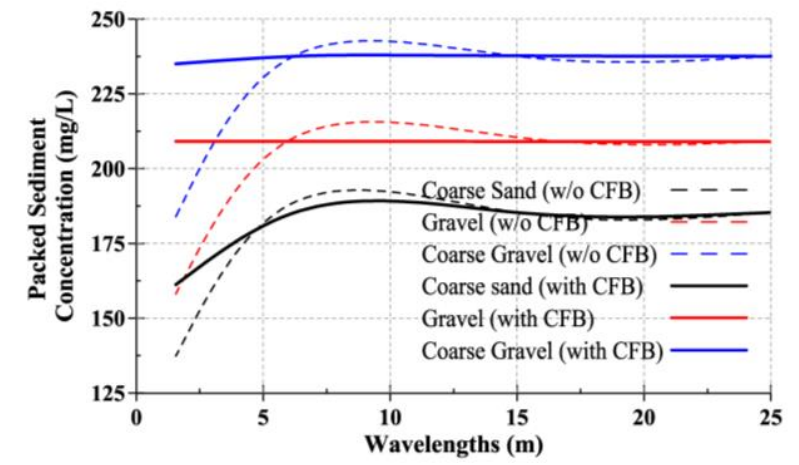

(a)

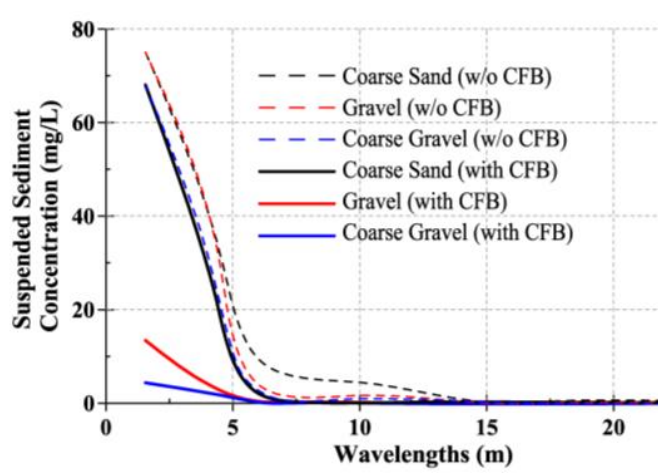

(b)

Figure 4. Average sediment concentration VS wavelength for (a) packed, (b) suspended.

From Figure 4(b), at the floor of the seabed, the average suspended sediment concentration, $\frac{m g}{L}$ for all species decreases with the presence of floating breakwater at $\mathrm{L}$ $=1.56 \mathrm{~m}$ (see Table 2). However, at $\mathrm{L}=6.239 \mathrm{~m}$, the sediment concentrations for gravel and coarse gravel without the breakwater are lower as compared to the one with breakwater but the difference was rather insignificant. Despite that, the reversed trend can be seen for coarse sand that shows higher concentration in the absence of the floating breakwater. Beyond this wavelength, the sediment concentrations for all species are almost the same with and without the floating breakwater. 
Figure 5 (a) and (b) depict the changes in total suspended sediment mass with wavelength. Generally, in the presence of floating breakwater, the average of total suspended and packed sediment mass, $\mathrm{g}$ for all species is much lower as compared to without floating breakwater. The detailed results are represented in Table 7. In the present study, with the absence of the $\mathrm{CFB}$, as the wavelength increases from $\mathrm{L}=1.56 \mathrm{~m}$ to $\mathrm{L}=24.94 \mathrm{~m}$, the decrement of the suspended mass were $51.11 \%, 56.4 \%$ and $60.13 \%$ for all the species. However, larger decrement of suspended sediment mass can be seen in the presence of CFB by $59.23 \%, 66.45 \%$ and $69.13 \%$ for coarse sand, gravel and coarse gravel, respectively, at a higher wavelength. Figure 5(a) shows that both cases exhibit a decrease in suspended sediment mass for all species from $\mathrm{L}=1.56$ to $6.239 \mathrm{~m}$ with a dramatic effect due to installation of CFB. In contrast, it is shown in Figure 5(b), that the packed sediment mass increases linearly for with and without floating breakwater but marked increment can be traced for the latter case. This can be attributed to the good wave damping effects of CFB, particularly for longer waves [14], while much wave energies are dissipated through turbulence, friction loss and flow reversal across the cage [28].

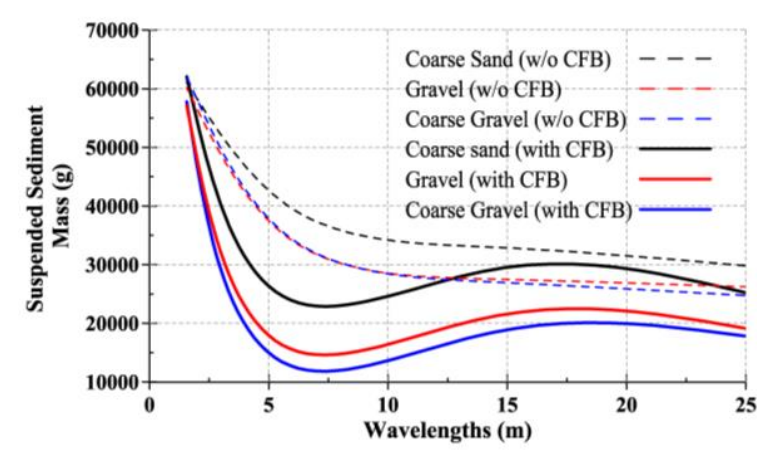

(a)

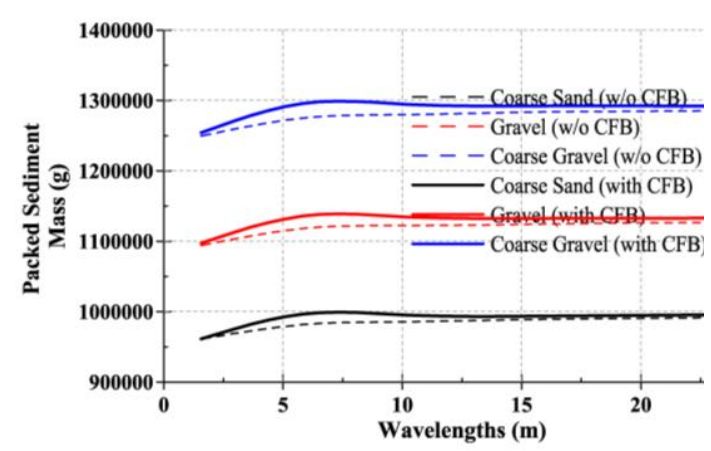

(b)

Figure 5. Average sediment mass VS wavelength for (a) suspended, (b) packed.

Table 7. Average suspended sediment mass (SSM).

\begin{tabular}{ccccccc}
\hline $\begin{array}{c}\text { Wavelength, } \\
\text { L }(\mathrm{m})\end{array}$ & \multicolumn{3}{c}{ SSM without FB $(\mathrm{g})$} & \multicolumn{3}{c}{ SSM with CFB $(\mathrm{g})$} \\
\cline { 2 - 7 } & $\begin{array}{c}\text { Coarse } \\
\text { sand }\end{array}$ & Gravel & $\begin{array}{c}\text { Coarse } \\
\text { gravel }\end{array}$ & $\begin{array}{c}\text { Coarse } \\
\text { sand }\end{array}$ & Gravel & $\begin{array}{c}\text { Coarse } \\
\text { gravel }\end{array}$ \\
\hline 1.5600 & 60993.80 & 60138.20 & 62049.25 & 61991.55 & 57072.83 & 57776.22 \\
6.2390 & 38889.85 & 33398.82 & 33608.83 & 23476.30 & 15153.92 & 12309.94 \\
14.0370 & 33029.58 & 27555.14 & 27095.65 & 28886.79 & 20861.73 & 18130.42 \\
24.9400 & 29817.45 & 26218.97 & 24737.02 & 25272.08 & 19147.15 & 17833.99 \\
\hline
\end{tabular}

Table 8. Average packed sediment mass (PSM).

\begin{tabular}{ccccccc}
\hline $\begin{array}{c}\text { Wavelength, } \\
\text { L }(\mathrm{m})\end{array}$ & \multicolumn{3}{c}{ PSM without FB $(\mathrm{g})$} & \multicolumn{3}{c}{ PSM with CFB $(\mathrm{g})$} \\
\cline { 2 - 7 } & $\begin{array}{c}\text { Coarse } \\
\text { sand }\end{array}$ & Gravel & $\begin{array}{c}\text { Coarse } \\
\text { gravel }\end{array}$ & $\begin{array}{c}\text { Coarse } \\
\text { sand }\end{array}$ & Gravel & $\begin{array}{c}\text { Coarse } \\
\text { gravel }\end{array}$ \\
\hline 1.5600 & 961959.8 & 1093967 & 1249434 & 961106.8 & 1097312 & 1254129 \\
6.2390 & 982671.2 & 1119292 & 1276313 & 997826.7 & 1137222 & 1297271 \\
14.0370 & 988438.0 & 1125352 & 1283172 & 992832.3 & 1132149 & 1292247 \\
24.9400 & 992000.1 & 1126809 & 1285600 & 995913.9 & 1133072 & 1291648 \\
\hline
\end{tabular}


Table 8 shows the average packed sediment mass before and after the installation of CFB. As the wavelength increases, the packed sediment mass decreases for all species due to the installation of CFB. In the case of $\mathrm{L}=1.56 \mathrm{~m}$, coarse sand species average mass seems to be higher in the presence of CFB but the difference is quite insignificant. The general trend of the packed sediment mass as increment of wavelength result in decrement by $17.99 \%, 36.93 \%$ and $38.71 \%$ for all species; coarse sand, gravel and coarse gravel at $\mathrm{L}=24.94 \mathrm{~m}$. Nevertheless, beyond this wavelength range, the simulated results become narrowed for the two cases. From $\mathrm{L}=1.56 \mathrm{~m}$ to $24.94 \mathrm{~m}$ the most packed sediment species is coarse gravel, followed by gravel and coarse sand. In short, Figure 4 and 5 show that the presence of CFB is able to control the diffusion of suspended load of sediment while limiting the loss of bulk sediment mass and concentration. Of course, in the future, different wave parameters can be investigated to support the findings. Notwithstanding, here we could present quantitatively and qualitatively the significant influences from the floating breakwater to the gradient of sediment transport based on the engineering judgement in literature $[29,30]$.

\section{Effect of Vertical Clearance between Floating Breakwater and Seabed}

Table 9 presents the total suspended sediment mass (TSM) and packed sediment mass (PSM) for various vertical clearances. All species showed an increment in total suspended mass from vertical clearance of $2.0 \mathrm{~m}$ to $6.0 \mathrm{~m}$. A rapid decrement for all species at $8.0 \mathrm{~m}$ in Figure 6(a) shows that the average total suspended sediment mass, g, for all species increases from clearance of $2.0 \mathrm{~m}$ to $6.0 \mathrm{~m}$. However, at the vertical clearance of $8.0 \mathrm{~m}$, the suspended sediment mass decreases sharply by $65.52 \%, 81.08 \%$ and $88.12 \%$ for coarse sand, gravel and coarse gravel, respectively. In Figure 6(b), the average total packed sediment mass, g, for all species shows a rather stagnant trend from clearance of $2.0 \mathrm{~m}$ up to $8.0 \mathrm{~m}$. The detailed results are completely summarized in Table 7. However, the gradient will result in a different force balance over the vertical and affect both bed shear stress and the main velocity field which contributes to the total packed sediment mass transport [31]. In Figure 7, the average suspended sediment concentration, $\frac{m g}{L}$, for all species decreases with increasing clearance with merely no change as the vertical clearance moves from $6.0 \mathrm{~m}$ to $8.0 \mathrm{~m}$ (see Table 10).

Table 9. Total suspended (TSM) and packed sediment mass (TPM) for varying clearance.

\begin{tabular}{|c|c|c|c|c|c|c|}
\hline \multirow{2}{*}{$\begin{array}{c}\text { Clearance } \\
\text { (m) }\end{array}$} & \multicolumn{3}{|c|}{ TSM (g) } & \multicolumn{3}{|c|}{ TPM (g) } \\
\hline & $\begin{array}{l}\text { Coarse } \\
\text { sand }\end{array}$ & Gravel & $\begin{array}{l}\text { Coarse } \\
\text { gravel }\end{array}$ & $\begin{array}{c}\text { Coarse } \\
\text { sand }\end{array}$ & Gravel & $\begin{array}{l}\text { Coarse } \\
\text { gravel }\end{array}$ \\
\hline 2 & 20876.80 & 13471.46 & 11312.13 & 1004042.00 & 1142927 & 1302874 \\
\hline 4 & 25785.93 & 19992.62 & 18897.66 & 998154.20 & 1135420 & 1294234 \\
\hline 6 & 27791.95 & 22008.02 & 19983.00 & 997467.50 & 1134929 & 1294766 \\
\hline 8 & 9582.37 & 4163.64 & 2374.79 & 1016422.00 & 1153757 & 1313311 \\
\hline
\end{tabular}

Table 10. Average suspended sediment concentration (SSC) for varying clearance.

\begin{tabular}{cccc}
\hline Clearance $(\mathrm{m})$ & \multicolumn{3}{c}{ SSC with CFB $(\mathrm{mg} / \mathrm{l})$} \\
\cline { 2 - 4 } & Coarse sand & Gravel & Coarse gravel \\
\hline 2 & $1.19507 \times 10^{-06}$ & $3.14554 \times 10^{-07}$ & $2.3762 \times 10^{-07}$ \\
4 & $1.01206 \times 10^{-07}$ & $1.93722 \times 10^{-08}$ & $1.48843 \times 10^{-08}$
\end{tabular}


6

8

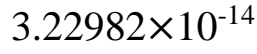

$1.15858 \times 10^{-14}$

$1.88279 \times 10^{-12}$

$9.72059 \times 10^{-14}$

$4.14171 \times 10^{-13}$

$1.03035 \times 10^{-13}$

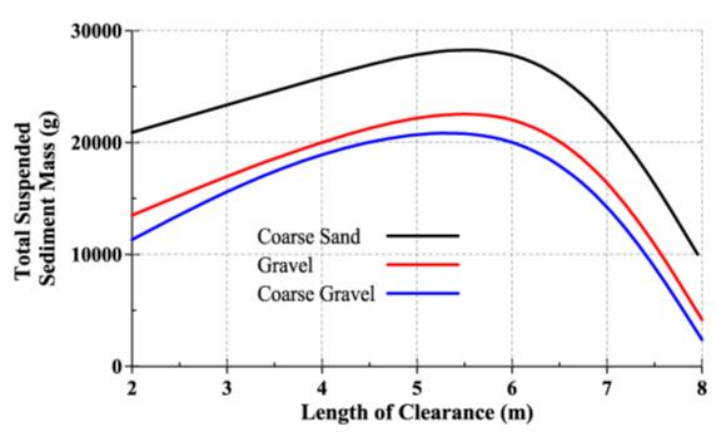

(a)

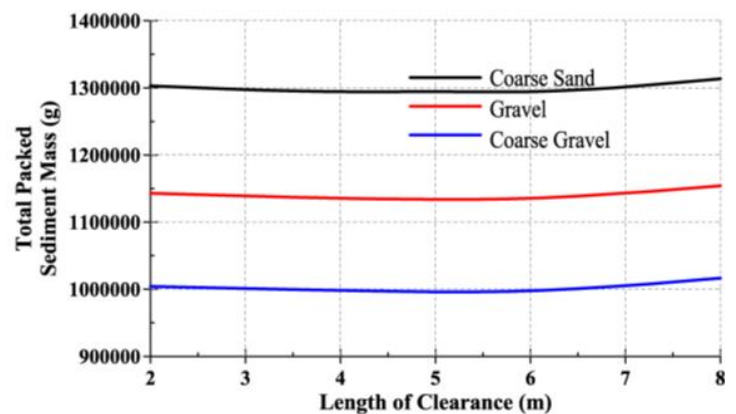

(b)

Figure 6. Total sediment mass vs. length of clearance for (a) suspended, (b) packed.

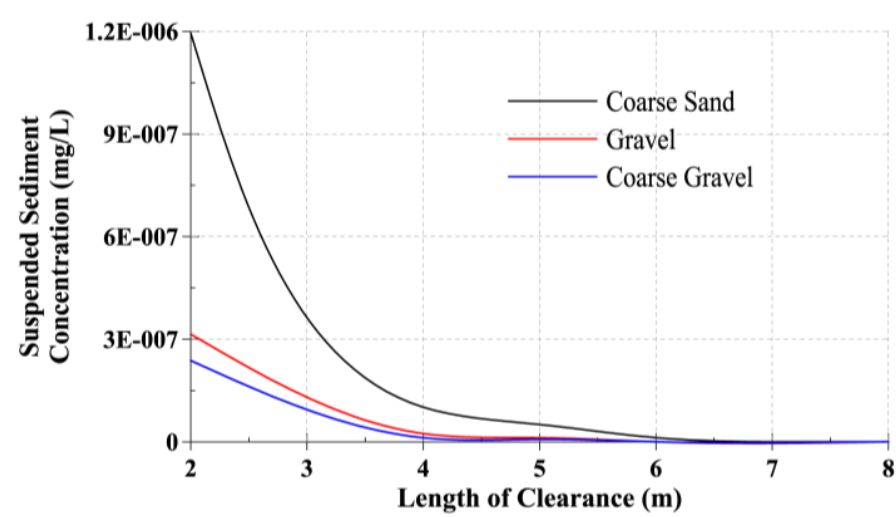

Figure 7. Average suspended sediment concentration vs. length of clearance.

\section{Mooring-line Tension}

Figure 8 shows the tension force trend at $\mathrm{L}=24.94 \mathrm{~m}$ for four mooring lines throughout the simulation time. It is convenient to explain that mooring Line 1 records the highest load followed by mooring Line 3. This is obviously because of these mooring lines located windward of the wave forcing. Based on the previous results, the mooring system seemed to successfully restrict the CFB motions by enabling the breakwater to effectively dissipate and reflect the wave energy which eventually limit the transport of sediment either as suspended or bed load. 


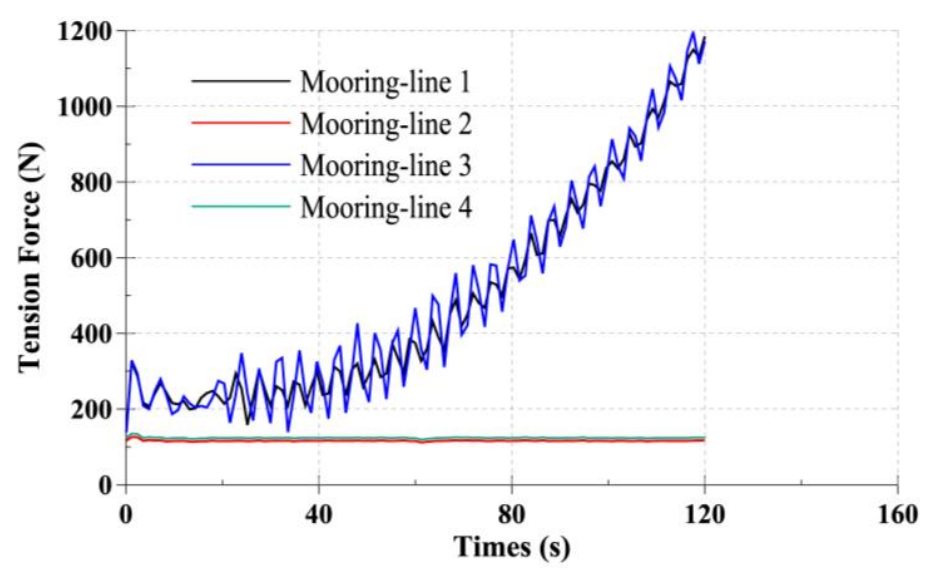

Figure 8. Magnitude of mooring line tension .

\section{CONCLUSIONS}

In the present paper, the wave-floating breakwater-sediment interactions under regular waves are deliberately simulated via computational fluid dynamics (CFD) approach. The CFD model is based on fully RANS equations and RNG model. The equations are discretised based on the Volume of Fluid method (TruVOF) and a sufficiently thin numerical grid is fitted to evaluate the fluid-structure interaction. The simulations were properly carried out to estimate the hydrodynamic scour of cylindrical floating breakwater (CFB). It can be concluded that:

- The suspended sediment concentration for all species with CFB is generally much lower than without floating breakwater at every wavelength by $97.35 \%, 99.37 \%$ and $99.05 \%$ for coarse sand, gravel and coarse gravel, respectively, while packed sediment concentration for all species generally show an insignificant increment.

- Increase of wavelength is associated with the decrement of suspended sediment mass by $0.39 \%, 0.55 \%$ and $0.47 \%$ while $15.24 \%, 26.97 \%$ and $27.91 \%$ for packed sediment mass with CFB relatively without CFB.

- It is noticed that the suspended sediment mass and concentration was more sensitive to the effect of clearance between the floating breakwater and seabed in comparison to the packed one due to highest clearance which resulted in a sharp decrement of $65.52 \%, 81.08 \%$ and $88.12 \%$ for all species.

Overall, the present results indicate that the cylindrical floating breakwater (CFB) is capable to satisfactorily control the mode of suspension and bed load transport for the environmental load considered.

\section{ACKNOWLEDGEMENTS}

The authors would like to thank to the Advance Computational Laboratory Maritime Technology, Universiti Malaysia Terengganu, Mr. Zulkifly bin Mohamed Adnan. His hospitality, support, and assistance during this computational model simulation took place are greatly acknowledge.

\section{REFERENCES}

[1] Biesheuvel AC. Effectiveness of Floating Breakwaters. Wave attenuating floating structures: Delft University of Technology; 2013. 
[2] Wang ZY. A Hydrodynamic Numerical Study on Twin-pontoon Type Floating Breakwater. Ann Arbor: Dalian University of Technology; 2011.

[3] Bayram A. Experimental study of a sloping float breakwater. Ocean Engineering. 2000;27:445-53.

[4] Williams A, Abul-Azm A. Dual pontoon floating breakwater. Ocean Engineering. 1997;24:465-78.

[5] Bhat SS. Performance of Twin-Pontoon Floating Breakwaters: University of British Columbia; 2009.

[6] Syed SA, Mani J. Performance of rigidly interconnected multiple floating pontoons. Journal of Naval Architecture and Marine Engineering. 2004;1:3-17.

[7] Chen X, Miao Y, Tang X, Liu J. Numerical and experimental analysis of a moored pontoon under regular wave in water of finite depth. Ships and Offshore Structures. 2017;12:412-23.

[8] Moghim MN, Botshekan M. Analysis of the performance of pontoon-type floating breakwaters. HKIE Transactions. 2017;24:9-16.

[9] Loukogeorgaki E, Yagci O, Kabdasli MS. 3D Experimental investigation of the structural response and the effectiveness of a moored floating breakwater with flexibly connected modules. Coastal Engineering. 2014;91:164-80.

[10] Peng W, Lee K-H, Shin S-H, Mizutani N. Numerical simulation of interactions between water waves and inclined-moored submerged floating breakwaters. Coastal Engineering. 2013;82:76-87.

[11] Wang HY. Experimental study and numerical simulation of a porous floating breakwater [Ph.D]. Ann Arbor: Dalian University of Technology; 2010.

[12] Murali K, Mani J. Performance of cage floating breakwater. Journal of Waterway, Port, Coastal, and Ocean Engineering. 1997;123:172-9.

[13] Gesraha MR. Analysis of $\Pi$ Shaped Floating Breakwater in Oblique Waves: I. Impervious Rigid Wave Boards. Applied Ocean Research. 2006;28:327-38.

[14] Ji C-Y, Chen X, Cui J, Yuan Z-M, Incecik A. Experimental Study of a New Type of Floating Breakwater. Ocean Engineering. 2015;105:295-303.

[15] Mani J. Design of Y-Frame Floating Breakwater. Journal of Waterway, Port, Coastal, and Ocean Engineering. 1991;117:105-19.

[16] Karambas TV, Samaras AG. An integrated numerical model for the design of coastal protection structures. Journal of Marine Science and Engineering. 2017;5(50):1-15.

[17] Flow3D 10.1.1 User Manual: Flow Science Inc.; 2013.

[18] Yakhot V, Orszag SA. Renormalization group analysis of turbulence. I. Basic theory. Journal of Scientific Computing. 1986;1:3-51.

[19] Yakhot A, Rakib S, Flannery W. Low-Reynolds number approximation for turbulent eddy viscosity. Journal of Scientific Computing. 1994;9:283-92.

[20] Koutsourakis N, Bartzis JG, Markatos NC. Evaluation of Reynolds stress, k- $\varepsilon$ and RNG k- $\varepsilon$ turbulence models in street canyon flows using various experimental datasets. Environmental Fluid Mechanics. 2012:1-25.

[21] Meyer-Peter E, Müller R. Formulas for Bed-Load Transport. IAHR; 1948.

[22] Van Rijn LC. Sediment transport, Part I: Bed load transport. Journal of Hydraulic Engineering. 1984;110:1431-56.

[23] Brethour J. Modeling sediment scour. Flow Science, Santa Fe, NM. 2003.

[24] Dirt and Mud-Densities. 2016.

[25] Lam S, Shuaib N, Hasini H, Shuaib N. Computational Fluid Dynamics Investigation on the Use of Heat Shields for Thermal Management in a Car 
Underhood. International Journal of Automotive and Mechanical Engineering. 2012;6:785-96.

[26] Saad I, Bari S. CFD investigation of in-cylinder air flow to optimize number of guide vanes to improve ci engine performance using higher viscous fuel. International Journal of Automotive and Mechanical Engineering. 2013;8:1096107.

[27] Wang B, Reeve D. Probabilistic modelling of long-term beach evolution near segmented shore-parallel breakwaters. Coastal Engineering. 2010;57:732-44.

[28] Murali K, Amer, S. S., Mani, J. S. Dynamics of cage floating breakwater. Journal of Offshore Mechanics and Arctic Engineering. 2005;127:331-9.

[29] Ozeren Y, Wren, D., Alonso, C. Experimental and numerical investigations of floating breakwater performance. Oxford, Mississippi 38655; 2009.

[30] Burgers RJW. Vryhof Floating Breakwater. Delft University of Technology; 1993.

[31] Jacobsen NG, Fredsoe J. Formation and development of a breaker bar under regular waves. Part 2: Sediment transport and morphology. Coastal Engineering. 2014;88:55-68. 